\title{
KAJIAN PERBANDINGAN TINGKAT PENGEMBALIAN DAN RISIKO ANTARA INVESTASI EMAS DAN SAHAM SYARIAH
}

\author{
Tais Khuron \\ BRI Syariah \\ Tais.khuron@gmail.com
}

\begin{abstract}
.
The objective of this research is to compare the return and risk between gold and shariah stocks. The measurement using the actual return between gold and shariah stocks, actual risk using standard of deviation between gold and shariah stocks, and the correlation between return and risk in gold and shariah stocks. The result shows that the stock's performance is better than gold in actual return, but gold has low risk if compare with the stocks. There are five stock that have a positive correlation with gold, such as: INTP, KLBF, SMGR, UNTR, and UNVR. TLKM stocks is the only one stock that has a negative correlation with gold.
\end{abstract}

Keywords: Return; Risk; Gold; Sharia Stocks

\begin{abstract}
Abstrak.
Penelitian ini bertujuan untuk membandingkan kinerja antara tingkat pengembalian dan risiko antara emas dan saham syariah. Perhitungan dilakukan dengan menghitung tingkat pengembalian aktual pada emas dan saham JII, tingkat risiko pada emas dan saham syariah, dan korelasi antara tingkat pengembalian dan risiko pada emas dan saham syariah. Hasil yang didapat menunjukkan kinerja saham masih lebih baik dibandingkan emas dalam hal tingkat pengembalian dalam jangka waktu 6 tahun karena tingkat pengembalian saham-saham lebih tinggi dibandingkan emas walaupun tingkat risiko emas lebih rendah dibandingkan saham-saham tersebut. Terdapat lima saham yang berhubungan positif dengan emas yaitu saham INTP, KLBF, SMGR, UNTR, dan UNVR. Saham TLKM menjadi satu-satunya saham yang berkorelasi negative dengan emas.
\end{abstract}

Kata Kunci: Tingkat Pengembalian; Risiko; Emas; Saham Syariah

Diterima: 5 Januari 2015; Direvisi: 28 Pebruari 2015; Disetujui: 10 Maret 2015 


\section{PENDAHULUAN}

Dalam ranah investasi, salah satu prinsip transaksi yang juga harus diperhatikan adalah tidak adanya paksaan, adil, saling menguntungkan, dan berupa kegiatan produksi atau penawaran jasa yang tidak dilarang oleh Islam, termasuk bebas manipulasi dan spekulasi. Dalam perspektif Islam, investasi, adalah kegiatan yang sangat dianjurkan karena dapat mendorong pertumbuhan ekonomi yang ditandai dengan meningkatnya transaksi jual-beli, simpan-pinjam, sewa-menyewa, gadai, dan kegiatan ekonomi lainnya. Pada dasarnya, investasi adalah memanfaatkan sumber daya (uang atau barang) untuk memperoleh keuntungan atau tambahan manfaat darinya. Investasi berarti penundaan konsumsi saat ini untuk konsumsi di masa yang akan datang. Investasi diawali dengan mengorbanan kegiatan konsumsi saat ini untuk mendapatkan manfaat yang lebih besar.

Investasi dibedakan menjadi dua, yaitu investasi pada aset keuangan dan investasi pada aset riil. Asset keuangan diperoleh pada lembaga keuangan, misalnya perbankan dan pasar modal. Deposito, saham, dan sukuk adalah contoh-contoh investasi pada aset keuangan. Sementara tanah, property, logam mulia, dan pabrik atau perusahaan adalah contoh-contoh investasi pada aset riil (Suryomurti, 2011).

Investasi modal yang sebaik-baiknya menurut al-Quran adalah tujuan dari semua aktivitas semua manusia hendaknya diniatkan untuk ibtighai mardhatillah (menuntut keridaan Allah). Dalam ungkapan lain, investasi terbaik itu adalah jika ia ditujukan untuk mencari ridha Allah (Ahmad, 2000). Terdapat bermacam-macam cara orang dalam melakukan investasi, diantaranya adalah dengan deposito syariah, investasi emas, investasi saham syariah, reksadana syariah, investasi sukuk, investasi properti maupun investasi dalam bentuk lainnya. Semua itu dilakukan oleh orang-orang yang mempunyai kelebihan modal hanya untuk mendapatkan keuntungan dimasa yang akan datang namun tetap sesuai dengan syariat Islam.

Masyarakat di Indonesia sebagian besar telah terbiasa dengan investasi emas, karena tidak sulit, dapat dilakukan oleh semua lapisan masyarakat dan investasi ini tergolong aman karena, harga emas cenderung stabil mengalami kenaikan dalam beberapa tahun ke depan. Serta investasi emas ini bukan spekulasi karena bersifat jangka panjang. Umumnya yang dilakukan oleh masyarakat dalam berinvestasi emas ialah dengan membeli sejumlah emas dengan modal yang kita punya,baik berupa emas perhiasan, emas lantakan atau emas koin. Kemudian emas tersebut disimpan untuk 
beberapa lama, kemudian di saat harga emas naik emas tersebut dijual. Selisih dari modal dan harga jual itulah yang disebut keuntungan. Logam mulia yang paling dikenal di dunia adalah emas dan perak. Kelebihan emas dibandingkan produk investasi lain adalah; pertama, nilainya cenderung naik setiap tahun (berkisar 20\%), dan kedua, likuid, dalam arti mudah dijual atau dicairkan. Dalam satu tahun terakhir, harga emas naik lebih dari $25 \%$ sementara dalam 10 tahun terakhir, harga emas melesat sekitar 420\% (Suryomurti, 2011).

Dilihat dari sejarah perkembangan harga emas yang setiap tahunnya rata-rata mengalami kenaikan di Indonesia membuat masyarakat tergiur untuk melakukan investasi emas dengan harapan di masa yang akan datang dapat memetik keuntungan dari hasil penjualan emas tersebut. Namun banyak kalangan juga menganggap berinvestasi emas adalah investasi yang sudah ketinggalan zaman seiring berkembangnya instrumen-instrumen investasi berbasis syariah lainnya yang juga tidak kalah menjanjikannya seperti jual beli saham syariah yang terdapat di pasar modal syariah. Sehingga banyak masyarakat yang memilih beralih untuk berinvestasi lewat pasar modal syariah dengan cara membeli saham-saham yang ada dengan harapan mendapat keuntungan yang lebih besar lagi.

Langkah awal perkembangan pasar modal syariah di Indonesia dengan diteritkannya reksa dana syariah pada 25 juni 1997 diikuti dengan diterbitkannya obligasi syariah pada akhir 2002. Kemudian JII diluncurkan pertama kali pada tanggal 3 Juli 2000 yang merupakan hasil kerja sama antara PT. Bursa Efek Jakarta (BEJ) dengan PT. Danareksa Investment Management (DIM). JII menggunakan tanggal awal perhitungan 1 januari 1995 dengan nilai awal 100 dan metode perhitungan indeks dilakukan sesuai dengan ketetapan BEI. Saham-saham yang terdapat dalam Jll dikategorikan telah lolos dari screening process yang dilakukan berdasarkan fatwa yang dikeluarkan oleh Dewan Syariah Nasional. Screening process dengan melihat rasio likuidnya berkisar antara $17-49 \%$, rasio pendapatan bunganya berkisar antara 5-15\% serta rasio utangnya $30-33 \%$. JII hanya menampung 30 saham dengan kinerja keuangan terbaik yang sudah sesuai dengan ketentuan syariah (Yunan, 2012).

Berdasarkan prinsip ekonomi Islam, investasi harus bebas dari unsur gharar (tidak pasti), maysir (judi), dan riba (bunga). Investasi dalam bentuk surat berharga bisa dikategorikan sebagai produk syariah, dengan syarat peraturan pelaksanaannya tidak bertentangan dengan syariah Islam tersebut. Tahun 2011, Majelis Ulama Indonesia (MUI) juga telah mengeluarkan fatwa tentang penerapan syariah di pasar modal dan 
Indeks Saham Syariah Indonesia (ISSI). Berdasarkan hasil keputusan Badan Pengawas Pasar Modal (Bapepam), surat berharga kategori syariah yang telah diterbitkan di pasar modal Indonesia meliputi Saham Syariah, Obligasi Syariah,dll.

Dalam melakukan investasi, ada dua faktor yang paling dipertimbangkan, yaitu pengembalian (return) dan risiko (risk) investasi. Dua faktor ini merupakan hal yang berlawanan, dalam arti investor menyukai pengembalian tinggi, sebaliknya mayoritas investor tidak mentukai risiko yang tinggi. Return merupakan imbalan yang diperoleh dari investasi. Sedangkan risk merupakan besarnya penyimpangan antara tingkat pengembalian yang diharapkan dengan tingkat pengembalian yang dicapai secara nyata. Semakin besar penyimpangannya berarti semakin besar tingkat risikonya (Yuliana, 2010).

Dari gambaran-gambaran di atas yang telah diuraikan, maka penulis tertarik untuk melakukan penelitian melalui studi komparasi mengenai keuntungan dan risiko antara investasi emas dengan investasi saham Jakarta Islamic Indeks (JII) periode 2008-2013. Karena dengan muncul banyaknya produk-produk investasi syariah pasti akan membuat perbedaan dalam hal keuntungan investasi jangka pendek maupun investasi jangka panjang

\section{METODE}

\section{Pengukuran Return Aset Tunggal}

Untuk menghitung tingkat actual return pada emas dan saham JII, dapat menggunakan rumus berikut (Jogiyanto, 2003):

$$
\begin{aligned}
& \text { Return = Capital Gain (Loss) } \\
& R_{t=} \frac{P_{t}-P_{t-1}}{P_{t-1}}
\end{aligned}
$$

Keterangan :

$R_{t} \quad$ :Return bulan ke-t

$P_{t} \quad$ :Harga pada bulan ke-t

$P_{t-1} \quad$ : Harga pada bulan sebelum bulan ke-t

Jika harga investasi sekarang $\left(P_{t}\right)$ lebih tinggi dari harga investasi periode lalu $\left(P_{t-1}\right)$ ini berarti terjadi keuntungan modal (capital gain), jika sebaliknya maka terjadi kerugian modal (capital loss).

Nilai yang diharapkan dari sebuah distribusi kemungkinan adalah penekanan rata-rata pada pada distribusi. Tekanan pada hal ini adalah kemungkinan-kemungkinan yang 
terkait dengan variabel investasi tersebut (Fabozzi, 2000). Return ekspektasi (expected return) adalah return yang diharapkan akan diperoleh investor di masa mendatang. Berbeda dengan return realisasi yang sifatnya sudah terjadi, return ekspektasi sifatnya belum terjadi. Return ini penting dibandingkan dengan return historis karena return ekspektasi merupakan return yang diharapkan dari investasi yang akan dilakukan. Untuk menghitung expected return diberi notasi $E(R)$ dengan data historis dapat dihitung menggunakan rumus (Jogiyanto, 2003):

$$
\mathrm{E}(\mathrm{R})=\frac{\sum_{t-1}^{n} R_{\mathrm{t}}}{N}
$$

Keterangan :

$$
\begin{aligned}
& \mathrm{E}(\mathrm{R}) \quad: \text { Expected return aset } \mathrm{i} \\
& \sum_{t-1}^{n} R_{t}: \text { Total return aset } \mathrm{i} \\
& \mathrm{N} \quad: \text { Jumlah periode bulanan }
\end{aligned}
$$

\section{Pengukuran Risiko Aset Tunggal}

Hanya menghitung return saja untuk suatu investasi tidaklah cukup. Risiko dari investasi juga perlu diperhitungkan. Pertimbangan suatu investasi merupakan trade-off dari kedua faktor ini. Return dan risiko mempunyai hubungan yang positif, semakin besar risiko yang harus ditanggung, semakin besar return yang harus dikompensasikan. Risiko sering dihubungkan dengan penyimpangan atau deviasi dari outcome yang diterima dengan yang diekspektasi. Van Horne dan Wachowics, (1992) mendefinisikan risiko sebagai variabilitas return terhadap return yang diharapkan. Untuk menghitung risiko, metode yang banyak digunakan adalah deviasi standar (standard deviation) yang mengukur absolut penyimpangan nilai-niai yang sudah terjadi dengan nilai ekspektasinya. Untuk mengukur risiko dengan standar deviasi dinyatakan sebagai berikut:

$$
\sigma=\frac{\sqrt{\sum_{i=1}^{n}\left(R_{i}-E(R)\right) 2}}{N-1}
$$

Keterangan :

$$
\begin{array}{ll}
\sigma & : \text { Standar Deviasi } \\
\mathrm{R}_{\mathrm{i}} & : \text { Return yang terjadi pada periode ke-i } \\
\mathrm{E}(\mathrm{R}) & : \text { Expected return } \\
\mathrm{N} & : \text { Jumlah periode bulanan }
\end{array}
$$




\section{Perhitungan Korelasi}

Koefisien korelasi menunjukan besarnya hubungan antara suatu variabel dengan variabel lainnya. Meskipun demikian, hubungan ini bukan merupakan hubungan Dengan demikian, nilai koefisien korelasi antara variabel A dan B. Untuk menentukan portofolio yang baik dan tepat, diperlukan memilih saham yang memiliki korelasi negatif satu sama lain. Korelasi negatif berarti kalau variabel yang satu naik, maka yang satunya akan turun, dan sebaliknya. Sedangkan kalau korelasinya positif, kalau variabel yang satu naik, variabel yang lain ikut naik. Demikian pula kalau variabel yang satu naik, variabel satunya akan ikut naik pula. Semakin memiliki korelasi yang negatif, semakin memiliki kemungkinan membentuk portfolio yang baik. Korelasi menunjukan besarnya hubungan antara dua variabel terhadap masing-masing risiko yang diperoleh.

\section{Pengukuran Return dan Risiko Portofolio}

Portfolio yang efisien didefinisikan sebagai portofolio yang memberikan return ekspektasi terbesar dengan risiko yang sudah tentu atau memberikan risiko yang terkecil dengan return ekspektasi yang sudah tertentu. Portofolio yang efisien ini dapat ditentukan dengan memilih tingkat ekspektasi tertentu dan kemudian meminimumkan risikonya atau menentukan tingkat tingkat risiko yang tertentu dan kemudian memaksimumkan return ekspektasinya (Jogiyanto, 2003).Tingkat return investasi emas yang didiversifikasikan dengan saham JII didapat dari penjumlahan antara pembobotan investasi emas dikalikan dengan return ekspektasi emas, ditambah dengan pembobotansaham JII dikalikan dengan return ekspektasi saham JII. Pembobotan investasi portofolio menggunakan skenario investasi dengan peningkatan pembobotan sebesar $10 \%$, yaitu:

- Skenario 1 : 10\% investasi emas dan 90\% saham JII

- Skenario 2 : $20 \%$ investasi emas dan $80 \%$ saham JII

- Skenario 3 : $30 \%$ investasi emas dan $70 \%$ saham JII

- Skenario 4 : 40\% investasi emas dan 60\% saham JII

- Skenario 5 : 50\% investasi emas dan 50\% saham JII

- Skenario 6 : $60 \%$ investasi emas dan $40 \%$ saham JII

- Skenario 7 : $70 \%$ investasi emas dan 30\% saham JII

- Skenario 8 : $80 \%$ investasi emas dan 20\% saham JII

- Skenario 9 : 90\% investasi emas dan 10\% saham JII

Hal ini bertujuan jika investasi emas mengalami kerugian yang cukup besar, maka investor masih memiliki alternatif keuntungan lain dari saham. Return portofolio dpat dihitung dengan rumus (Husnan, 1998): 


$$
E\left(R_{p}\right)=X_{A} E\left(R_{A}\right)+X_{B} E\left(R_{B}\right)
$$

Keterangan:

$\begin{array}{ll}E\left(R_{p}\right) & : \text { tingkat keuntungan yang diharapkan dari portofolio } \\ X_{A} & : \text { pembobotan investasi emas } \\ E\left(R_{A}\right) & : \text { Expected return emas } \\ X_{B} & : \text { Pembobotan investasi saham } \\ E\left(R_{B}\right) & : \text { Expected return saham }\end{array}$

Selain menghitung return portofolio seorang investor juga harus menghitung risiko yang mungkin akan terjadi dalam portofolionya. Tingkat risiko portofolio dapat dihitung dengan rumus (Husnan, 1998):

$$
\sigma_{p}=\left(X_{A}^{2} \sigma_{A}^{2}+X_{B}^{2} \sigma_{B}^{2}+2 X_{A} X_{B} \sigma_{A B}\right)^{1 / 2}
$$

Keterangan:

$\sigma_{\mathrm{p}} \quad$ : Standar deviasi portofolio

$\mathrm{X}_{\mathrm{A}} \quad$ : pembobotan investasi emas

$\sigma_{A}^{2} \quad:$ Varian emas

$X_{B} \quad$ : Pembobotan investasi saham

$\sigma_{\mathrm{AB}} \quad$ : Koefisien korelasi emas dengan saham

\section{HASIL DAN PEMBAHASAN}

Salah satu indikator yang digunakan dan mudah untuk memprediksi kinerja emas dengan saham-saham syariah ialah dengan cara melihat perkembangan return kedua instrumen investasi itu sendiri. Pengukuran kinerja ini dilakukan dengan melihat tingkat pengembalian dari tahun ke tahun selama periode penelitian yaitu dari tahun 2008 hingga tahun 2013. Hal ini dimaksudkan agar dapat lebih bisa menampilkan hasil secara detail dan mengetahui berapa besar persentase perubahan return tiap periodenya. Adapun berikut ini adalah penjelasan hasil perkembangan return emas dan saham-saham JII dari tahun 2008 hingga 2013:

Berdasarkan pada Tabel 1 terlihat bahwa tingkat pengembalian emas fluktuatif setiap tahunnya. Terlihat bahwa terjadi penurunan return dari tahun 2008 ke tahun 2009 yang awalnya berada pada kisaran 0,16410252 atau $16,41 \%$ turun menjadi 0,10519483 atau $10,52 \%$, sedangkan untuk return tertinggi berada pada kisaran 0,22209821 atau $22,21 \%$ yaitu tepatnya pada tahun berikutnya yaitu tahun 2010 dan dapat dilihat pula return terendah berada pada kisaran $-0,05417125$ atau $-5,42 \%$ yaitu tepatnya pada tahun 2013. Dengan demikian artinya apabila seorang investor ingin mendapatkan tingkat pengembalian yang tinggi, maka pada tahun 2010 lah waktu yang tepat 
karena harga emas sedang beranjak naik setelah di tahun sebelumnya mengalami penurunan.

Tabel 1. Tingkat Return Emas dari 2008 - 2013

\begin{tabular}{ccc}
\hline Tahun & Total $\mathbf{R}_{\mathbf{i}}$ & $(\%)$ \\
\hline 2008 & 0,16410252 & $16,41 \%$ \\
2009 & 0,10519483 & $10,52 \%$ \\
2010 & 0,22209821 & $22,21 \%$ \\
2011 & 0,12309714 & $12,31 \%$ \\
2012 & 0,16384464 & $16,38 \%$ \\
2013 & $-0,05417125$ & $-5,42 \%$ \\
\hline
\end{tabular}

Sumber: Data diolah, 2014

Berdasarkan data bahwa return ekspektasi (rata-rata return) emas tertinggi berada pada tahun 2010 yaitu sebesar 1,85\%. Artinya return yang diharapkan oleh investor sebesar $1,85 \%$ perbulan pada tahun 2010 . Sedangkan untuk rata-rata return terendah berada pada tahun 2013 pada kisaran $-0,45 \%$. Maka jika investor emas melakukan investasi sampai tahun 2012 masih bisa mendapatkan rata-rata return yang positif.

Risiko menyatakan seberapa jauh tingkat hasil yang diperoleh bisa menyimpang atau tidak sesuai yang diharapkan. Risiko ini secara kuantitatif dapat diukur dengan standar deviasi yang diberi lambang $\sigma$ (sigma). Semakin besar dispersi tingkat hasil yang diharapkan, semakin tinggi pula risiko investasi tersebut. Standar deviasi ini mengukur sebaran dari expected return atau average return, sehingga standar deviasi berhubungan langsung dengan variabilitas tingkat hasil yang diharapkan. Dengan mengukur tingkat risiko melalui standar deviasi, investor dapat mengetahui secara detail sejauh mana investasi tersebut berisiko setiap periodenya.

Berdasarkan pengolahan yang telah dilakukan, nilai standar deviasi emas tertinggi berada pada tahun 2008 yang berada pada kisaran 8,44\%. Hal ini berarti investor emas bisa mendapatkan return sebesar $16,41 \%$ pada tahun 2008 , maka memiliki kemungkinan menyimpang menjadi $7,97 \%(16,41 \%-8,44 \%)$ atau menjadi $24,85 \%(16,41 \%+8,44 \%)$ dan standar deviasi terendah berada pada tahun 2010 yang berada pada kisaran 3,84\%. Hal ini bermakna bahwa investor emas bisa memperoleh return sebesar $22,21 \%$ pada tahun 2010 , maka memiliki kemungkinan menyimpang menjadi $18,37 \%(22,21 \%-3,84 \%)$ atau menjadi $26,05 \%(22,21 \%+$ $3,84 \%)$.

Setelah mengetahui bagaimana tingkat pengembalian dan tingkat pengembalian yang diharapkan dari masing-masing kinerja emas dan saham-saham JII, barulah sekarang kita membandingkan manakah diantara kedua instrumen investasi tersebut yang lebih 
unggul dan lebih baik pada periode 2008 - 2013. Untuk mengetahui kinerja mana yang lebih unggul dari kedua instrumen investasi tersebut, berikut hasil analisis total return dan expected return emas dan saham JII Berdasarkan Gambar 1 dibawah menggambarkan bagaimana perkembangan return pertahun selama periode penelitian yaitu dari 2008 sampai dengan 2013. Terlihat bahwa return tertinggi dihasilkan oleh saham UNTR yaitu sebesar 1,40475070 atau sebesar 140,48\% pada tahun 2009. Kemudian return terendah dihasilkan oleh saham KLBF sebesar -1,04824635 atau sebesar $-104,82 \%$ pada tahun 2008. Di tahun 2009 hampir seluruh return saham mengalami kenaikan, hanya saja tidak begitu terhadap emas karena di tahun 2009 emas mengalami penurunan yang awalnya di tahun 2008 sebesar 0,16410252 atau sebesar $16,41 \%$ trurn menjadi $10,52 \%$. Sementara return tertinggi untuk emas berada pada kisaran $22,21 \%$ pada tahun 2010 .

\section{Gambar 1. Tingkat Return Emas dan Saham JII per tahun} Periode 2008 - 2013

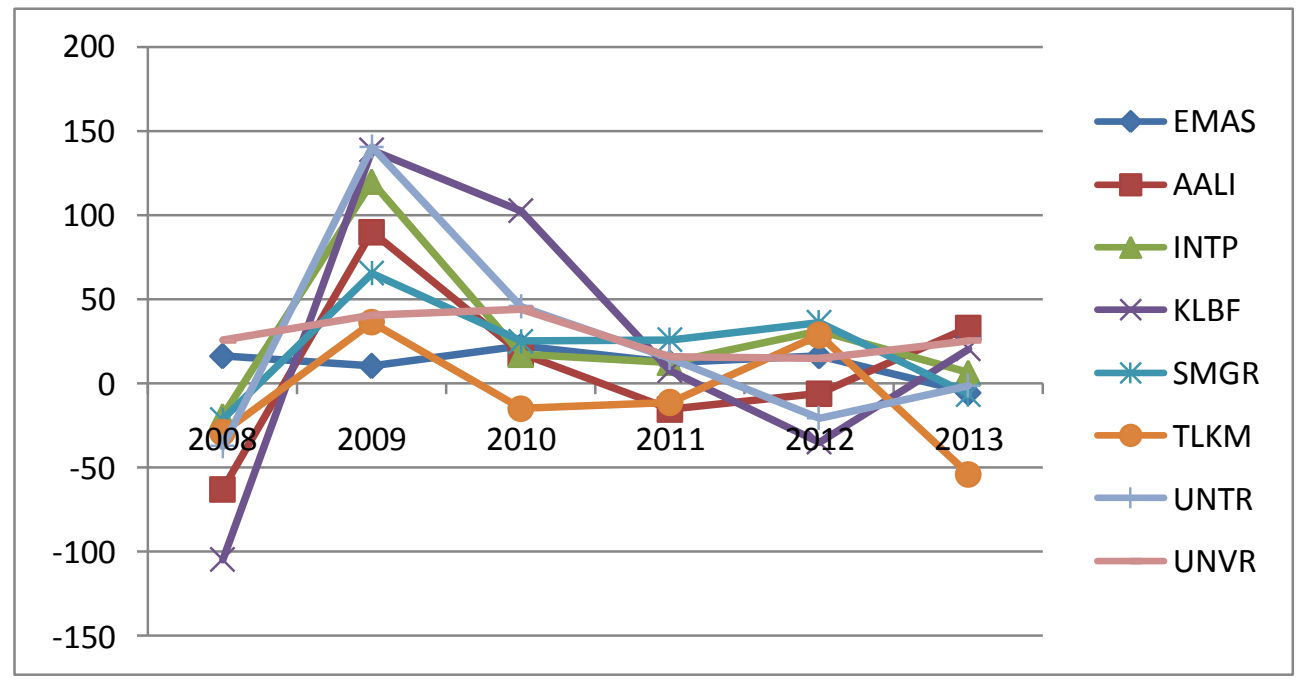

Sumber : Data diolah, 2014

Total return yang terjadi selama periode 2008 sampai dengan 2013 pada Tabel 2 dibawah adalah hasil yang dicapai dari suatu pengembalian dari investasi yang ditanamkan pada emas dan saham tanpa memperhitungkan faktor-faktor risiko yang terkandung didalamnya. Hasil total return yang merupakan penjumlahan dari total return selama periode penelitian, didapatkan bahwa emas dan saham AALI, INTP, KLBF, SMGR, UNTR dan UNVR selama periode penelitian mempunyai return positif, sedangkan untuk saham TLKM mempunyai return yang negatif, ini menunjukan bahwa perusahaan tersebut tidak dalam kinerja yang baik dan mudah terpengaruh oleh sentimen-sentimen negatif. Saham UNVR menghasilkan total return tertinggi yaitu 
1,6645 atau sekitar $166,45 \%$ dan total return terendah dihasilkan dari saham TLKM yang berada pada kisaran $-0,4488$ atau $-44,88 \%$. Sedangkan untuk total return emas berada pada kisaran 0,72416610 atau sekitar $72,41 \%$ masih jauh berada dibawah return saham. Ini berarti kinerja saham berdasarkan total tingkat pengembalian masih jauh lebih baik dibandingkan total tingkat pengembalian emas selama periode 6 tahun.

\section{Tabel 2. Peringkat Kinerja Emas dan Saham JII Berdasarkan Total Return pada} Periode 2008 - 2013

\begin{tabular}{ccc}
\hline No. & Produk Investasi & Total Return \\
\hline 1 & UNVR & $166,45 \%$ \\
2 & INTP & $154,54 \%$ \\
3 & UNTR & $141,48 \%$ \\
4 & KLBF & $129,92 \%$ \\
5 & SMGR & $124,46 \%$ \\
6 & EMAS & $72,41 \%$ \\
7 & AALI & $56,62 \%$ \\
8 & TLKM & $-44,88 \%$ \\
\hline
\end{tabular}

Sumber : Data diolah

Berdasarkan data terlihat bahwa sama halnya dengan Gambar 1 kinerja saham UNTR menghasilkan rata-rata return pertahun tertinggi yaitu sebesar $11,71 \%$ pada tahun 2009. Sedangkan untuk rata-rata tingkat pengembalian terendah berada pada kisaran -8,74 yaitu hasil dari saham KLBF pada tahun 2008. Jika dilihat dari data terlihat bahwa kenaikan dan penurunan tingkat rata-rata emas cukup stabil dan tidak ada penurunan maupun kenaikan yang drastis. Ini menandakan bahwa emas cukup stabil dalam hal tingkat rata-rata pengembalian selama periode penelitian walaupun selalu berada di bawah saham. Hasil dari expected return yang merupakan pembagian dari total return dibagi jumlah periode penelitian, periode pada peneitian ini berjumlah 6 tahun. Didapatkan bahwa nilai expected return tertinggi dihasilkan oleh saham UNVR mencapai 0,2774 atau sekitar $27,74 \%$ dan nilai yang diharapkan terendah berada pada kisaran $-7,48 \%$ yang dihasilkan oleh saham TLKM. Sedangkan emas menghasilkan expected return sebesar $12,07 \%$. Nilai ini lagi-lagi masih jauh berada dibawah expected return sahamsaham JII. Dilihat dari hasil kinerja berdasarkan nilai yang diharapkan (expected return) ternyata emas masih kalah jauh di bawah kinerja saham-saham JII untuk jangka waktu periode 6 . 
Tabel 3. Peringkat Kinerja Emas dan Saham JII Berdasarkan Rata-rata Pengembalian pertahun Periode 2008 - 2013

\begin{tabular}{ccc}
\hline No. & Produk Investasi & Rata-rata Return pertahun \\
\hline 1 & UNVR & $27,74 \%$ \\
2 & INTP & $25,76 \%$ \\
3 & UNTR & $23,58 \%$ \\
4 & SMGR & $21,65 \%$ \\
5 & KLBF & $20,74 \%$ \\
6 & EMAS & $12,07 \%$ \\
7 & AALI & $9,44 \%$ \\
8 & TLKM & $-7,48 \%$ \\
\hline
\end{tabular}

Sumber : Data diolah, 2014

Jika dilihat dari hasil penelitian dimana return dan expected return emas memiliki return dan expected return dibawah saham-saham JII, hal ini merupakan hal yang kurang menguntungkan untuk berinvestasi emas, tapi untuk pertumbuhan jangka panjang. Hasil tersebut dapat berubah seiring perkembangan pasar yang mendukung pertumbuhan investasi emas secara global di seluruh dunia. Hal tersebut dapat kita lihat bahwa pertumbuhan return emas relatif lebih stabil dibandingkan return sahamsaham JII dan pertumbuhan tersebut dapat terus berlanjut sehingga mempengaruhi pendapatan yang lebih menguntungkan bagi investor. Sesuai dengan tujuan jangka panjang, maka sebaiknya investor melakukan investasi emas pada jangka panjang karena proses dari hasil emas ini tidak dapat dinikmati secara instan dan dalam jangka waktu yang sedikit.

Hasil olahan data terkait standar deviasi, menunjukkan bahwa investasi saham KLBF menghasilkan risiko tertinggi yaitu sebesar 25,07\% pada tahun 2012 dan risiko yang hampir serupa juga terjadi pada tahun berikutnya pada tahun 2013 yaitu giliran saham TLKM yang menghasilkan risiko yang tinggi yaitu sebesar 25,05. Sementara untuk risiko terendah dihasilkan oleh saham TLKM pada tahun 2011 yaitu sebesar 3,17\%.

Tabel 4. Peringkat Kinerja Emas dan Saham JII Periode 2008 - 2013

\begin{tabular}{ccc}
\hline No. & Produk Investasi & $\sigma$ \\
\hline 1 & EMAS & $6,84 \%$ \\
2 & UNVR & $7,57 \%$ \\
3 & SMGR & $9,45 \%$ \\
4 & INTP & $11,40 \%$ \\
5 & TLKM & $12,42 \%$ \\
6 & AALI & $13,22 \%$ \\
7 & UNTR & $13,69 \%$ \\
8 & KLBF & $16,39 \%$ \\
\hline
\end{tabular}

Sumber :Data diolah, 2014 
Berdasarkan perhitungan peringkat standar deviasi atau risiko pada Tabel 4 terhadap emas dan saham-saham JII secara keseluruhan selama periode 2008 sampai dengan 2013 terlihat bahwa risiko yang paling besar justru dihasilkan oleh saham KLBF yaitu sebesar 0,16394524 atau sebesar 16,39\% padahal saham KLBF berada di peringkat 4 dan 5 dalam total return dan expected return. Ini menandakan bahwa saham KLBF cukup berisiko karena meiliki return yang tidak terlalu tinggi namun mempunyai risiko yang cukup tinggi. Kemudian untuk standar deviasi terendah dimiliki oleh emas dengan kisaran 0,06842627 atau sebesar 6,84\%. Ini membuktikan bahwa emas adalah investasi yang memang tidak terlalu tinggi dalam hal pengembalian namun risiko yang dihasilkan sangat rendah dibandingkan saham-saham JII.

\section{Tabel 5. Perbandingan Total Return, Rata-rata Return dan Standar Deviasi}

\begin{tabular}{cccc}
\hline Investasi & Total Return $\left(\mathbf{R}_{\mathbf{i}}\right)$ & Rata-rata Return $\mathbf{E}\left(\mathbf{R}_{\mathbf{i}}\right)$ & Standar Deviasi $(\boldsymbol{\sigma})$ \\
\hline EMAS & $72,41 \%$ & $12,07 \%$ & $6,84 \%$ \\
AALI & $56,62 \%$ & $9,44 \%$ & $13,22 \%$ \\
INTP & $154,54 \%$ & $25,76 \%$ & $11,40 \%$ \\
KLBF & $129,92 \%$ & $21,65 \%$ & $16,39 \%$ \\
SMGR & $124,46 \%$ & $20,74 \%$ & $9,45 \%$ \\
TLKM & $-44,88 \%$ & $-7,48 \%$ & $12,42 \%$ \\
UNTR & $141,48 \%$ & $23,58 \%$ & $13,69 \%$ \\
UNVR & $166,45 \%$ & $27,74 \%$ & $7,57 \%$ \\
\hline
\end{tabular}

Sumber: Data diolah, 2014

Analisis korelasi yang dilakukan menggambarkan bagaimana hubungan antara emas dengan saham-saham JII apakah berhubungan positif atau negatif. Jika dicermati hubungan antara emas dengan saham AALI sangat lemah terbukti terlihat bahwa nilai korelasi antara emas dan saham AALI sebesar 0,056 0,5 dengan tingkat signifikansi $0.641>0,05$. Kemudian untuk hubungan antara emas dengan saham INTP, saham KLBF, saham SMGR, saham UNTR dan saham UNVR berhubungan positif dan cukup kuat dengan nilai korelasi masing-masing saham INTP sebesar 0,810, saham KLBF sebesar 0,564, saham SMGR sebesar 0,818, saham UNTR sebesar 0,678 dan saham UNVR sebesar 0,822 dengan tingkat signifikansi yang sama yaitu 0,000 0,05 yang berarti terdapat korelasi yang signifikan. Artinya ada kemungkinan apabila return emas naik maka saham-saham tersebut juga akan ikut naik dan sebaliknya apabila return emas turun maka return saham-saham tersebut pun akan ikut turun. Hubungan yang kuat antara emas dengan saham INTP, KLBF, SMGR, UNTR dan UNVR terbukti adanya kenaikan harga emas dan saham -saham di tahun 2009 dan begitu juga sebaliknya harga emas dan saham secara bersamaan mengalami penurunan di tahun 2011 otomatis mempengaruhi tingkat pengembalian emas dan saham di tahun tersebut. 
Jika dilihat dari tabel korelasi terlihat bahwa satu-satunya saham yang berkorelasi negatif dengan emas yaitu saham TLKM sebesar -0,081 dengan tingkat signifikansi 0,497 . Artinya apabila return emas naik maka return saham TLKM akan mengalami penurunan dan sebaliknya apabila return emas turun maka return saham TLKM akan mengalami kenaikan. Portofolio yang baik dan tepat dapat dilihat dengan melihat korelasi investasi yang paling negatif. Dalam penelitian ini, saham TLKM merupakan saham yang layak untuk dapat diportofoliokan dengan emas, karena memiliki korelasi paling negatif dengan emas. Saham TLKM, merupakan saham perusahaan yang bergerak di bidang telekomunikasi. Perusahaan ini menyediakan produk maupun jasa untuk kebutuhan masyarakat dalam hal berkomunikasi yang sangat penting untuk saat ini, sehingga dalam kondisi apapun, perusahaan ini akan tetap akan tetap mendapatkan keuntungan karena masyarakat pasti membutuhkan produk dan layanannya.

Return potofolio merupakan keuntungan yang diharapkan oleh investor dari portofolio yang dilakukan. Dalam penelitian ini, ditemukan bahwa emas berkorelasi negatif dengan saham TLKM, yang berarti emas dapat diportofoliokan dengan saham TLKM tersebut. Pembentukan portofolio antara emas dan saham TLKM perlu juga diperhatikan return dan risiko yang akan diperoleh investor, agar investor dapat menerima return yang tinggi dengan risiko yang tidak terlalu tinggi. Dengan kata lain pembentukan portofolio ini adalah cara dimana meminimalisirkan risiko apabila hanya pada satu investasi. Dalam penelitian ini, perhitungan return dan risiko portofolio antara emas dan saham TLKM dihitung berdasarkan masing-masing skenario pembobotan untuk melihat apakah portofolio emas dan saham TLKM menghasilkan return dan risiko yang baik ataukah menghasilkan return dan risiko yang kurang baik atau hanya salah satu saja yang lebih menguntungkan.

Berdasarkan data terlihat bahwa skenario pembobotan $100 \%$ emas dan $0 \%$ saham TLKM merupakan return tertinggi, namun juga memberi risiko yang cukup tinggi pula. Skenario pembobotan yang paling memberikan risiko paling tinggi dihasilkan dengan pembobotan investasi $0 \%$ emas dan 100\% saham TLKM dimana skenario tersebut juga memberikan return terendah. Ini membuktikan walaupun saham TLKM berkorelasi negatif sehingga dapat diportofoliokan dengan emas namun investor harus tetap melihat tingkat return yang diharapkan karena nilai tersebut sangat berpengaruh terhadap hasil dari portofolio. 
Tabel 6. Return dan Risiko Portofolio Emas dan Saham TLKM

\begin{tabular}{cccc}
\hline \multicolumn{4}{c}{ PORTOFOLIO INVESTASI } \\
EMAS & RETURN & RISIKO & TLKM \\
\hline $0 \%$ & $-0,0748$ & 0,1242 & $100 \%$ \\
$10 \%$ & $-0,0552$ & 0,1012 & $90 \%$ \\
$20 \%$ & $-0,0357$ & 0,0820 & $80 \%$ \\
$30 \%$ & $-0,0161$ & 0,0667 & $70 \%$ \\
$40 \%$ & 0,0030 & 0,0445 & $60 \%$ \\
$50 \%$ & 0,0229 & 0,0478 & $50 \%$ \\
$60 \%$ & 0,0425 & 0,0442 & $40 \%$ \\
$70 \%$ & 0,0621 & 0,0444 & $30 \%$ \\
$80 \%$ & 0,0816 & 0,0485 & $20 \%$ \\
$90 \%$ & 0,1011 & 0,0565 & $10 \%$ \\
$100 \%$ & 0,1207 & 0,0684 & $0 \%$ \\
\hline
\end{tabular}

Sumber: Data diolah, 2014

Risiko terendah, dapat dicapai dengan posisi skenario pembobotan $60 \%$ di emas dan $40 \%$ di saham TLKM dengan nilai return sekitar 4,25\% dan risiko sebesar 4,42\%. Artinya di skenario ini return emas menutupi rendahnya return saham TLKM dan sebaliknya saham TLKM mengurangi risiko emas. Jika dicermati lebih lanjut bahwa jika investor berinvestasi dibawah $40 \%$ di emas yang artinya berinvestasi diatas $60 \%$ di saham TLKM akan memberikan return negatif dan sangat berisiko, ini menandakan bahwa kinerja saham TLKM selama 2008 hingga 2013 sangat kurang baik, terbukti bahwa tingkat return saham TLKM selalu berada dalam posisi negatif selama 4 tahun yaitu pada tahun 2008 sebesar -29,17\%, tahun 2010 sebesar 14,96\%, tahun 2011 sebesar $-11,40 \%$ dan tahun 2013 sebesar $-54,02 \%$.

Penurunan return saham TLKM setiap tahunnya ini dipengaruhi karena menurunnya kinerja perusahan tersebut dikarenakan banyaknya persaingan di bidang tekomunikasi di Indonesia yang semakin maju dan berkembang. Berbeda dengan emas yang hampir selalu konsisten naik di setiap tahunya, karena setiap tahun selalu terjadi peningkatan permintaan terhadap emas di seluruh dunia. Jadi berdasarkan penelitian return dan risiko portofolio di atas sebaiknya hanya berinvestasi di emas saja karena melihat rendahnya return yang dihasilkan saham TLKM.

Yunan dan Rahmasari (2014) mengukur kinerja saham yang terdaftar di Jakarta Islam Index dengan menggunakan Indeks Sharpe, Indeks Treynor, dan Indeks Jensen. Berdasarkan ketiga parameter tersebut diperoleh saham dengan peringkat kinerja terbaik yaitu AALI, ANTM, ASII, CPIN, INDF, KLBF, LSIP, dan UNTR. Beik dan Fatmawati (2015) melakukan penelitian terkait pengaruh indeks harga saham syariah internasional dan variabel makroekonomi terhadap Jakarta Islamic Index (JII). Hasil studi menunjukkan bahwa JII dipengaruhi secara positif dan signifikan oleh DJIEU, 
DJIMY dan IPI, serta dipengaruhi secara negatif dan signifikan oleh DJIJP, IMUS, M2 dan SBIS. JII paling cepat mencapai kestabilan ketika merespon guncangan terhadap jumlah uang yang beredar (M2)

\section{SIMPULAN}

Dilihat dari hasil return dan risiko masing-masing antara emas dan saham-saham JII selama periode penelitian tahun 2008 sampai dengan 2013, emas masih berada jauh dibawah saham hanya menghasilkan total return sebesar $72,41 \%$ dan risiko sebesar 6,84\%, jauh berada dibawah saham INTP, KLBF, SMGR, UNTR dan UNVR. Berdasarkan hasil yang diperoleh dari perhitungan kinerja berdasarkan return dan risiko emas dibandingkan saham-saham JII selama periode 6 tahun dari tahun 2008 sampai dengan 2013 terlihat bahwa kinerja dengan total pengembalian tertinggi ialah saham INTP (Indocement Tunggal Prakarsa Tbk), kemudian diikuti dengan saham UNVR (Unilever Indonesia Tbk), saham UNTR (United Tractors Tbk), saham KLBF (Kalbe Farma Tbk), saham SMGR (Semen Indonesia Tbk), emas, saham AALI (Astra Agro Lestari) dan yang terakhir saham TLKM (Telekomunikasi Indonesia Tbk). Dapat dikatakan kinerja saham masih lebih baik dibandingkan emas dalam hal tingkat pengembalian dalam jangka waktu 6 tahun karena tingkat pengembalian saham-saham lebih tinggi dibandingkan emas walaupun tingkat risiko emas lebih rendah dibandingkan saham-saham tersebut.

Berdasarkan hasil perhitungan korelasi terdapat 5 saham yang berhubungan positif dengan emas yaitu saham INTP, KLBF, SMGR, UNTR dan UNVR. Kelima saham tersebut mempunya hubungan yang cukup kuat yakni semuanya bernilai > 0,5 dan saham TLKM menjadi satu-satunya saham yang berkorelasi negatif dengan emas yaitu sebesar -0,081 dengan tingkat signifikan 0,497>0,05 yang artinya bisa untuk dijadikan portofolio dengan emas, sehingga menghasilkan return dan risiko portofolio tertinggi sebesar 0,1207 dengan risiko 0,0684 dengan kombinasi pembobotan $100 \%$ emas dan $0 \%$ saham TLKM dikarenakan rendahnya expected return saham TLKM yang berada di posisi negatif sebesar $-7,48 \%$. Artinya saham TLKM adalah saham dengan return terkecil dan sangat berisiko sehingga lebih baik apabila hanya berinvestasi di emas. 


\section{PUSTAKA ACUAN}

Ahmad, M. 2000. Etika Bisnis dalam Islam. Jakarta: Pustaka Al-Kautsar.

Beik, I.S. dan S.W. Fatmawati. 2014. Pengaruh Indeks Harga Saham Syariah Internasional dan Variabel Makroekonomi Terhadap Jakarta Islamic Index. Allqtishad: Jurnal IImu Ekonomi Syariah (Journal of Islamic Economics), Vol. 6 (2), hlm. 155-178

Fabozzi, F.J. 2000. Manajemen Investasi. Jakarta: Salemba Empat.

Husnan, S. 1998. Dasar-dasar Teori Portfolio dan Analisis Sekuritas. Yogyakarta: AMP YKPN.

Jogiyanto. 2003. Teori Portfolio dan Analisis Investasi. Yogyakarta: BPFE Yogyakarta

Suryomurti, W. 2011. Super Cerdas Investasi Syariah. Jakarta: Agromedia Pustaka

Yuliana, I. 2010. Investasi Produk Keuangan Syariah. Malang: UIN Maliki Press.

Yunan, Z.Y. dan M. Rahmasari. 2015. Measurement of Shariah Stock Performance Using Risk Adjusted Performance. Al-lqtishad: Jurnal IImu Ekonomi Syariah (Journal of Islamic Economics), Vol. 7 (1), pp. 127-140 